\title{
Mobilizing the Rural People of Nigeria towards Sustainable Development: A Study of Akwa Ibom State
}

\author{
${ }^{1}$ Kingdom Sunday Mboho, Ph.D., ${ }^{2}$ Tahirir Emmanuel Udousoro, M.Sc., ${ }^{3}$ \\ Unwana-Abasi Sunday Udo, M.Sc. \\ ${ }^{I}$ Department of Public Administration Faculty of Social and Management Sciences Akwa Ibom State University \\ Nigeria, ${ }^{2}$ Department of Sociology University of CalabarCross River State Nigeria, ${ }^{3}$ Department of Public \\ Administration faculty of Social and Management Sciences Akwa Ibom State University Nigeria
}

\begin{abstract}
Sustainable development has been the central focus of contemporary development discuss. It has assumed an important place in the rhetoric of the development giants and the governments of developing countries. This study was primarily focused on assessing the impact of the mobilization approach on the sustainable development efforts of the rural people in Akwa Ibom State with emphasis on how it affects their quality of living condition as well as meeting their real (felt) needs. The study applied the participatory appraisal technique in identifying the various approaches and strategies employed by the government and nongovernmental agencies to mobilize the people towards sustainable rural development programmes. The study employed a descriptive survey design, and was conducted in the 3 senatorial districts of the state using a sample of 537 respondents, randomly selected from 3 Local Government Areas in each of the senatorial districts. A total of 9 Local Government Areas and 36 villages were used as sample area of the study. The analysis of the data was done using the descriptive statistics (simple percentages (\%) to analysis the research questions. The findings of this study showed, among other things that there are quite a good number of strategies/techniques/approaches employed by government to involve the local peasants in self sustaining development programmes. The study recommends that for meaningful sustainable development of the rural areas to take place, government should not only educate the people, but should use the bottom-up approach by making enormous use of the existing local organizations in the formation and implementation of development strategies
\end{abstract}

Keywords: Sustainable Development, Mobilization, Rural Development, Felt Needs, Industrialization, and Strategies.

\section{Introduction}

Rural life in Nigeria to date is synonymous with poverty, alienation, and socio-economic, deprivation. Every facet of life is associated with subsistence, while life expectancy is comparatively very low (Ekong, 2010). Governments in many developing countries including Nigeria have engaged in the development of strategies to improve the lives and potentials of the rural people.

Development has been considered as an integrated process with social and political, as well as economic and administrative dimensions (Nwachukwu, 2011). For this reason, two important questions are analyzed and discusses. First, is the questions of the need for, and the extent of the participation of rural people in rural development decisions which, of course, affect their lives. The second question has to do with the nature of the relationship or linkages which should exist between local non-governmental organizations and various levels of governmental structure which make and implement policies and programmes aimed at providing services, allocating resources, and exerting influence on the rural development process (Ekpo and Uwatt, 2005).

Considering the above question, two approaches have emerged which help to explain the reality of inter-organizational relationship and people's participation in the rural development process (Nwachukwu, 2013). The first is the paternalistic approach which assumes that rural dwellers are passive, uninterested in improving their social and economic conditions, and are incapable of taking initiative in making these improvements. The rural people are therefore viewed from this perspective as being incapable of maintaining development at the grass roots level. The application of this approach according to Ekong (2010), is that, in order to accelerate the pace of social and economic development of the rural areas, the central government and its administration must provide all useful initiatives. Consequently, the pattern of development activity that emerges is a top-down one in which rural people are always the objects or recipients of central ideas, plans, and services. In this pattern of dependent relationship with the central government, the rural communities are expected only to carry out directives and show appreciation for the services provided for them. 
The second and opposing perspective is the populist approach which perceives the rural dwellers as vitally interested in development, and is capable of transforming their communities with or without the assistance of the central administration.

However, the above approaches do not in the real sense reflect of the rural development process in the sense that, they represent ideal situations which deny the existence of complementarities among the various forms and levels of organization for development. This is because local organizations which are separated and isolated from the state and central governments are unlikely to acquire adequate resources (such as highly trained and competent staff, finance, information, equipment and so on) which could have enabled them to make meaningful impact on development. Also, there is the need on the part of local organizations to link their development efforts to the overall plans of the state and central governments, (Nwachukwu, 2013).

The shortcoming of these approaches to development in the rural areas stimulated in recent years, the search for an alternative approach. This led to the emergence of the integrated rural development approach (the mobilization approaches) which was recently adopted by government in tackling the problems of the rural poor. This approach is different from other general development approaches because it places greater emphasis on the mobilization and development of human resources potential and on achieving a more equitable access to resources and faire distribution of income. This led to the establishment of Mass Mobilization for self Reliance and Economic Recovery (MAMSER) and the Directorate for Food, Roads and Rural Infrastructure (DFRRI) as the basis for ensuring sustainable development in the rural areas using the mobilization approach, (DFRRI, 1988; MAMSER, 1987).

Inspite of all the strategies and programmes, life expectancy amongst the majority of Nigerian people, especially those of the rural societies still remains very low. The above condition therefore, indicates that the rural dwellers require not only programmes and projects to get developed, but also real mobilization to actualize any programme or strategy that is geared towards such purpose. In line with the mobilization concept, Ojo and Jibowo, (2002) opine that for human society to be developed, there must be a direct involvement of the people in capacity building, greater self reliance, creativity, self-discipline, responsibility and material to regulate all forms of relationship within the social system. To them also, rural mobilization involves the transformation of the conditions of rural dwellers into a desirable one aimed at improving the quality of life of the rural population, (Ekong, 2010; Nwachukwu, 2013).

As part of the various attempts at sustainable development of the rural people, mobilization has been an important strategy for involving them in development programmes. In line with the above, the researcher believes that mobilization as important strategies should be employed to improve the lives of the rural poor for sustainable development in Nigeria and Akwa Ibom State in particular.

\section{Operational Definition Of Concepts}

Mobilization: Mobilization implies encouraging rural people, through special techniques/strategies to appreciate and take active part in any development strategy introduced by either the federal or state government; or international/non-governmental organizations.

Rural Development: According to World Bank, (1980), rural development is defined as strategies and policies designed at improving the economic and social life of a specific group of people.

Felt Needs: These are needs which reflect the aspirations, goals, and basic necessities of a people. They are seen as basic needs-aimed at achieving a better quality of life of a people.

Sustainable Development: Refers to as economic and social development that meets the needs of the current generation without endangering the ability of future generations satisfying their needs and choosing their lifestyle.

\section{The Concepts Of Mobilization For Sustainable Development}

In order to explain the meaning of mobilization, social scientists often employ certain strategies, movements and campaigns to explain this concept. Generally, political and military leaders usually mobilize their people for war, or consolidate the economic conditions of their people through diverse strategies.

The term "social mobilization" was coined by Karl Deutsch who gave it a substantial meaning and an operational definition. Social mobilization as defined by him, is the process in which major clusters of old social, economic and psychological commitment are eroded or broken and people become available for new pattern of socialization and behaviour, (Coulter, 1975). It is what happens to a large number of people in areas that are undergoing the process of modernization.

According to the Directorate of Social Mobilization, (1987), mobilization is the process of pooling together, harnessing, actualizing and utilizing potential human resources for the purpose of development. It is a process whereby human beings are also motivated and energized to collectively utilize such resources for the improvement of their spiritual and material conditions of living. 
Social mobilization is a consequence of modernization. It occurs in two stages: Firstly by breaking the people away from old habits, customs, values, expectations and commitments; and secondly, the induction of the mobilized persons into new patterns of group membership organization and commitment. Three group are mobilized out of or from their conventional and traditional past into new patterns of values, socialization and behaviour.

In the context of this study, social mobilization is a continuous process as it takes place in both the developed and developing societies, as no society can completely eliminate all traces of traditionalism. Social mobilization takes place not only after the people been made to abandon their traditional setting including their values, expectations, attitudes and have become free from the clutches of traditionalism, but also involve active participation in development affairs.

Social scientists argue that, mobilization must have a clear sense of ideological direction. To them, a solid set of principles should guide mass mobilization efforts. In line with the white paper on the report of the political Bureau, social mobilization in Nigeria was to be effected within the framework of Nigeria's five national goals; that is, our collective resolve to build:

i. $\quad$ A United, strong and self-reliant nation.

ii. A great and dynamic economy.

iii. A just and egalitarian society.

iv. $\quad$ A land of bright and full opportunities for all citizens.

v. A free and democratic society (Nwachukwu, 2011).

The argument behind mobilization is that, it is the human resources of nation that ultimately determine the nature, direction and pace of its socio-economic development. In other words, nations are built essentially through the creative, productive and innovative hard-work of the people themselves (Ekong, 2010).

From the perspective of mobilizing the potentials of rural people, it is clear from the general conception of mobilization that, any nation which fails to develop the skills and productive talents of her people (both in urban and in rural areas), and to effectively mobilize and utilize such skills to transform the material economy, will be unable to achieve real development. This is why there is an urgent call for the mobilization of the potentials of the rural people of Akwa Ibom State. Such mobilizations will poster rapid and all round development for the country.

\section{The Living Conditions Of People In The Rural Areas OfAkwa Ibom State}

Since sustainable development is focused on improving the quality of life of people, and is also people centred, it is deemed necessary to take a cursory look at some indices of the living conditions of people in the rural areas of the state under study.

The condition of Nigeria's rural majority in general has been presented many times in economic, social, organizational and health terms. Nearly all accounts are gloomy and some describe both the present state and the speed of change in the pattern of living standards of the rural people. According to Akpabio, (2005), after many years of political independence in Nigeria, neither the living conditions of the rural majority nor the basis of economic and political power (concentrated in the hands of a few elite) has changed significantly. Consequently, the rural poor have not contributed significantly to rural and national development nor have they been able to share from the benefits arising from national growth.

McNamara, (1991), submits that there is a high rate of rural poverty in most developing countries, and the most rural people are living in such conditions that are so limited by malnutrition, illiteracy, disease, squalid surroundings, high infant mortality and low life expectancy. This picture is not different from the Nigerian rural sector (especially rural areas in Akwa Ibom State). The Nigerian rural sector was neglected in the colonial era and has still not witnessed any major transformation in the post independence era.

Nwachukwu, (2011), described the Nigerian rural setting as being made up of Nigeria's neglected rural majority who lacked all the essential amenities such as health contres, good access roads, and electricity, modern market facilities, banks, well equipped schools, potable water, recreational facilities and good housing. Ekong, (2010), further describes the poor socio-economic conditions of the rural sector by describing it as "the other Nigeria" with poverty-linked characteristics which include illiteracy, low income, superstition, poor family planning, high rate of mortality and morbidity, as well as certain social norms like the extended family system and the caste system. Often times, these norms have deep-rooted cultural understanding.

In Akwa Ibom State, the quality of life or social conditions of people in the rural areas could be reflected in the state of education, state of health, economic infrastructure like roads, electricity, water and sanitation, housing conditions etc, and the distribution of economic opportunities. All these exist in diverse forms of efficiency and adequacy, and consequently affect individual economic activities and opportunities, (Ekpo and Uwatt, 2005).

According to Okorji and Awa, (1992), a major consequence of the disparity in infrastructural and other welfare facilities in rural and urban areas is the increased rate of migration of people, especially the youths, from 
rural to the urban centres in search of better means of livelihood. This persistent increase in the rate of outmigration has resulted in fewer hands on the form, which in turn, poses a serious threat to survival given the present fast increase in population growth as well rising demands for food.

\section{Inherent Problems In Mobilizing The Peasantry For Rural Development}

Previous development programmes and policies failed to mobilize the Nigerian peasantry for the socioeconomic improvement of rural life. As the study by Adegboye, (2004), showed, the government "has made rural conditions worse even though it consistently tended to give the impression that agriculture and the rural sector are among the key priority areas of attention". Similarly, Akpabio, (2005), founded a generally low level of overall income... (and) a serious degree of absolute impoverishment among the $30 \%$ to $40 \%$ of house-holds in rural Northern Nigeria.

This worsening of rural conditions by state's agricultural policies has been attributed to a number of inter-related variables viz:

i. Wrong economic ideology which emphasized large-scale, capital-intensive agriculture, thereby displacing peasants and engendering the under-utilization of the country's most vital and abundant resourcehuman labour.

ii. Defective bureaucratic structures due to bad leadership, inept officialdom, inefficient management and poor staffing, culminating in widespread mismanagement and embezzlement of agricultural development funds. iii. Low agricultural prices deliberately set by the government to control agricultural surpluses, making it difficult for small-scale farmers to expand on their production levels, to earn the younger generation to accept farming as an occupation.

iv. Non existent (or weak) peasant organizations due to state coercion, thereby excluding the peasants from participating in the formation, implementation and evaluation of agricultural policies and programmes.

v. Private or state land ownership system which fostered rural aristocracy and land speculation, thereby obliterating the traditional communal land tenure system that had stimulated increased agricultural production before and during colonial rule.

vi. Excessive taxation of peasants that diminished their propensities to save or invest in new productive agricultural technology.

vii. Materialistic national culture that gingered excessive concern with material possession (i.e wealth and property) rather than moral or intellectual values, thereby enabling a minority rushing class to private public agricultural resources (e.g capital, land, technology and social services) and to develop the consciousness to fight against the success of rural development because it would erode their dominant class privilege.

\section{Rural Industrial Development In Akwa Ibom State For Sustainable Development}

With industrialization as one of the quickest means for generating employment and new business opportunities for the people, the state government decided to set up the Akwa Ibom Industrial and Investment Promotion Council (AKIIPOC) as the vehicle for achieving industrial development objectives. This decision was based on the bitter experiences of the past where the management of government industrial establishments through direct government supervision has left an unenviable record, (SES, 2000).

AKIIPOC has accelerated the reaction of the Champion Breweries Plc., strategic new industries have received new attentions. For example, AKIlPOC has already incorporated Akwa Petroleum and Energy Ltd. (APEL) with four subsidiaries viz:

i. APEL Exploration and Production.

ii. APEL Refinery.

iii. APEL Gas.

iv. APEL Power, (SES, 2000).

With the incorporation of these industries came the development of basic infrastructure like power, water, roads, etcetera. The fact is that, most of these companies are sited in communities which are rural in nature. The resultant effect will be the benefits that the people enjoy when these companies take off in terms of employment.

\section{Imperativeness Of Mobilization For Sustainable Development In Akwa Ibom State}

The stark imperativeness of mobilization for sustainable development of Akwa Ibom State becomes obvious on the very date the state was created and Uyo decreed as its state capital. The state's compactness and the close proximity to Uyo, the state capital, and all its constituent parts and local government areas were considered a rare asset for the rapid and sustainable development of the young-state (Abasiekong, 1994). Because of these structural features, it was felt that most workers in the civil service and others would travel from their rural base to Uyo, the State Capital to work and return. Such arrangement, it was believed greatly relieved the state capacity of the traffic jams characteristics of most Nigerian state capitals. It was also hoped 
that this arrangement would reduce to the barest minimum the overstretching of the already insufficient facilities such as water, electricity, schools and transportation in the state, (Ekong, 2010).

Faced with a large proportion of rural population and its attendant problems, and determined to improve or alter the state's ugly landscape and integrate its citizens into the mainstream of economic, social and political development, the pioneer government of the state and its successors adopted varying strategies for Sustainable Development. Overarching all other development strategies adopted in the state has been the Directorate of Food, Roads and Rural Infrastructure (DFRRI) established by President Babangida in 1986, with the mandate among other things: to identify, involve and support viable local community organizations; in the effective mobilization of the population for sustained development activities bearing in mind the need for promoting greater community participation and economic self-reliance of the rural community.

Further more, the Akwa Ibom State government has embarked on the implementation of the following policies of sustainable development in the rural areas.

i. Electrification and provision of electricity to many rural communities.

ii. Sinking of thousands of bore-holes in rural communities throughout the state.

iii. $\quad$ Opening and grading of many feeder roads which were unmotorable.

iv. Establishment of open markets and supermarkets in the rural areas, tailored to promote and widen local markets for the rural dwellers to limit them with wholesalers and middlemen in the urban areas.

v. Establishment of health centres and dispensaries in the rural areas.

vi. Embarking on the policy of building and rehabilitating community centres such as village council halls, youth viewing plaza, as well as the policy to create recreational parks and motor parks in the rural areas with a view to providing relaxation (Ekpot et al, 2004; Ekong, 2010).

A cursory look at the above policy trust of the state government as regards sustainable development of its rural areas suggests that questions be asked on how these rural peasants who are the perceived beneficiaries of such policy are properly mobilized. Rural people have a significant part to play in ensuring sustainable development and livelihood-by being aware of their priorities, in their choice of project of leaders, in locating where, when and how to initiate projects and the benefits of the projects to the rural people.

\section{Methodology}

The study was based on descriptive survey design, since it enabled the researcher to collect data from respondents without imposing any condition on them. The respondents were asked information through questionnaire as the research instrument. The design for this study outlined stages and the procedures need in order to accomplish the goals of the investigation, such procedures included the identification of the population, selection of sample size, selection of respondents, data collection and analysis. It was conducted in the three (3) senatorial districts of the state using a sample of 537 respondents, randomly selected from 3 L.G.A in each of the senatorial districts. A total of 9 L.G.As and 36 villages were used as sample areas and the population comprises titled chiefs, other indigenes, and residents of the communities. Data collected from both the primary and secondary sources through the use of questionnaire, books, journals, among others, were collected, presented and analyzed with the help of descriptive statistics simple percentage (\%).

\section{Data Presentation and Interpretation of Results.}

Data were collected mostly through the use of questionnaire. Copies of the questionnaire were circulated to the people found in the study sites selected for the study.

\section{ANALYSIS OF RESEARCH QUESTION 1}

What are the various strategies employed to mobilize the rural people of Akwa Ibom State for sustainable development?

Tables 1: Response Pattern of Research Question One

\begin{tabular}{|c|c|c|c|c|c|}
\hline RESPONSES & UYO & $\begin{array}{c}\text { IKOT } \\
\text { EKPENE }\end{array}$ & EKET & TOTAL & $\%$ \\
\hline Formation of committees & 42 & 61 & 49 & 152 & $(28.3 \%)$ \\
\hline Opinion leaders & 41 & 24 & 23 & 88 & $(16.4)$ \\
\hline Cooperative societies & 21 & 30 & 46 & 91 & $(16.9)$ \\
\hline Community Development Association (CDA) & 53 & 27 & 59 & 159 & $(29.6)$ \\
\hline Ethnic Associations & 20 & 13 & 14 & 47 & $(8.8)$ \\
\hline Total & 177 & 175 & 185 & 537 & (100.0) \\
\hline
\end{tabular}

Source: Field survey, 2013

From table 1, it was observed that, factors such as formation of committees, opinion leaders, traditional rulers, co-operative societies; Community Development Association's and ethnic associations served as mobilization 
strategies. The table shows that, people vary in their opinions. It is observed that, of the 537 respondents, 153 $(28.3 \%)$ of them mentioned that formation of committees is one of the ways to get the people mobilized; $88(16.4 \%)$ of respondents observed that people could be mobilized through opinion leaders; $91(16.9 \%)$ of the respondents believed that mobilization is associated with traditional rulers. Also, $159(29.6 \%)$ of the respondents believed that people were mobilized when they belong to co-operative societies; while $47(8.8 \%)$ held that people were mobilized when they form and belong to ethnic associations.

ANALYSIS OF RESEARCH QUESTION 2

What appropriate mobilization strategies could facilitate sustainable development in Akwa Ibom State?

Tables 2: Response Pattern of Research Question Two

\begin{tabular}{|c|c|c|c|c|c|}
\hline RESPONSES & UYO & $\begin{array}{c}\text { IKOT } \\
\text { EKPENE }\end{array}$ & EKET & TOTAL & $\%$ \\
\hline Mobilize along rural potentials & 38 & 24 & 33 & 95 & $(17.7 \%)$ \\
\hline Involve the people in the planning & 39 & 40 & 37 & 116 & $(21.6)$ \\
\hline Mobilize for local needs & 57 & 48 & 41 & 146 & $(27.2)$ \\
\hline Give rewards during mobilization & 23 & 39 & 46 & 108 & $(20.1)$ \\
\hline Use indigenes all the time & 20 & 24 & 28 & 72 & $(13.4)$ \\
\hline Total & 177 & 175 & 185 & 537 & (100.0) \\
\hline
\end{tabular}

Source: Field survey, 2013

Table 2 shows that, above one-sixth (17.7\%) recommended that mobilization should be channeled along local potentials; a little above one-fifth $(21.6 \%)$ requested that, the local people should be involved in the planning for mobilization. Also, a little above two-fifth $(27.2 \%)$ asked for mobilization that takes care of local needs. About one-fifth $(20.1 \%)$ emphasized that, the local people who are involved should be appropriately rewarded financially; while a little above one-eight (13.4\%) recommended that for proper mobilization to take place, indigenes must be involved.

\section{Discussion Of The Findings}

Not withstanding the anomalies characterizing government interventionist development programme/project, government efforts at mobilizing instrumental local organizations have been very significant.

The mobilization approach to development is not without some implementation problems. This is because like so many development approaches/programmes, it is bedeviled with a lot of implementation pitfalls. Using the qualitative research methods and the findings of this study, most mobilization strategies fail to materialize in the study area due to the following factors:

- Wrong conceptual design and planning;

- Incorrectly specified objectives.

- Wrong timing of mobilization strategies which may neither be too short (making it impossible to complete action), not too long (creating complacency and apathy).

- Ineffective planning, monitoring and evaluation of development strategies.

From all dimensions, and using available indices such as level of participation, availability of mobilization mechanism, as well as availability of development projects/programmes in the various study areas; the findings of this study therefore confirms a high degree of effective and efficient mobilization strategies among the people.

The present mobilization strategies will not only sustain development in the rural areas, but will ensure sustained livelihood, if the problems currently bedeviling it may reduced to the brearest minimum.

\section{Conclusion}

The instrument of mobilization has been seen as one of the effective strategies for ensuring selfsustained development in most societies. There is enormous evidence that various mechanisms such as Community Development Associations (CDA's), Non-Governmental Organization (NGO's), Cooperatives, Village Committees, Ethnic Associations, Opinion Leaders etc are complementing government development efforts in mobilizing the rural people. Given enormous support, and appropriate policy environment, they could fill so much gaps where government agencies have limitations in mobilizing the rural populace.

It is vividly clear that greater mobilization and participation of the rural poor in satisfying their own needs through the establishment of self-reliant, self-governing, peasant groups and organizations, is a necessary concomitant for ensuring sustained development of rural communities. 


\section{Recommendations}

What is observed in this study is that mobilization is still a varitable instrument for rapid rural sustainable development. Despite this acknowledgement, adequate strategy for mobilization has not been put in place. It is observed that, government alone could not address the whole question of rural Sustainable Development. In an attempt to bring about an urgent and fundamental development and sustainable prosperity through mobilization, the following recommendations are made:

i. Development should be people centered or oriented. They should be involved in the planning and implementation of any development strategy and this should be based on people's needs.

ii. The basic philosophy under mobilization of the rural people should be self reliance, that is, reliance, on local human and natural resources. Within the framework of self-reliance, needs should be related to the available resources and the expectation of the people.

iii. Since mobilization is intended to reduce poverty, the co-operative societies should be clearly re-designed and re-organized along an egalitarian line. This will encourage more rural people to join cooperative societies so as to share in the benefits.

iv. As much as possible, the training of local leadership should be intensified. This will enhance sustainability in areas that are already mobilized.

v. Government should make enormous use of the existing organizations in the development and implementation of her rural development strategies, which will make the strategies more participating and "bottom-up" in approach.

\section{References}

[1]. Abasiekong, E. M. (1982). Integrated Rural Development in Third World: Its Concepts, Problems and Prospects, New York Press, New York.

[2]. Abasiekong, E. M. (1994). Community Organization and Development in Nigeria. In Abasiekong, E. M. and Modo, I.V.O. (eds.) High Points in Development. Dorand Publishers, Uyo.

[3]. Akpabio, E. B. (1994). Crossroads in Nigerian Development: A Programme of Action for a Better Nigeria. New Generation Publishers; Port Harcourt.

[4]. Coulter Philip (1975). Social Mobilization and Liberal Democracy: Health and Company, Lexington DC.

[5]. DFRRI (1988). Rural Development: The mobilization Approach. Federal Government Press, Lagos.

[6]. Ekpenyong, S. (2001). Sustainable Livelihoods and Job Creation in the Niger Delta Area. Proceeding of a Conference Organized by the Niger Delta Development Commission (NDDC).

[7]. Ekpenyong, S. (2008). Elements of Sociology: Davidstones Publisher Ltd. Port Harcourt, Nigeria.

[8]. Ekong, E. E. (2010). Rural Sociology $\left(3^{\text {rd }}\right)$. An introduction and Analysis of Rural Nigeria. Dove Educational Publishers, Uyo, Nigeria.

[9]. Ekpo, A. H. and Uwatt, B. (2005). Akwa Ibom State of Nigeria: Poverty Profile and Economic Transformation. Foundation for Economic Research and Training Press, Uyo.

[10]. Ekpot, I. D.; Inyang, E. U.; Umoren, N. J. (2004). Agricultural Resources Management: The Wag Forward (Addressing Policy Priorities for Rural Development). Workshop Paper Published by Economic Network of Civil Societies, Uyo.

[11]. MAMSER, (1987). Improving the Spiritual and Material Conditions of Living among Nigerian Rural Women, Lagos.

[12]. McNamara, V. J. (1998). Population Resources and the Environment: The Critical Challenge. UNFPA

[13]. Nwachukwu, I. and Ekwe, K. C. (2011). Globalizaiton and Rural Development in Nigeria. Extension Centre, Michael Okpara University of Agriculture, Umudike.

[14]. Nwachukwu, I. (2013). Agricultural Extension and Rural Development Promoting Indigenous Knowledge. Lamb House Publications, Umuahia.

[15]. Ojo, M. O. and Jibowo, A. A. (2002). Co-operatives an Instrument for Grass Roots Mobilization for Rural Development. Nigerian Journal of Rural Sociology. 3(1 and 2): $10-18$

[16]. Okorji, E. C. and Ania, E. O. (2002). Strategies of Rural Development in Nigeria in Olomola, A. A. and Nwosu, A. C. (eds). Rural Development Strategies in Nigeria. Nigerian Rural Sociological Association.

[17]. World Bank (1980). Poverty and Human Development. Oxford University Press, New York. 